\title{
Towards modular regionalism: the proliferation of Latin American cooperation
}

\author{
Em direção a um regionalismo modular: a proliferação \\ da cooperação latino-americana
}

http://dx.doi.org/10.1590/0034-7329201500111

GIAN LUCA GARDINI*

Rev. Bras. Polít. Int. 58 (1): 210-229 [2015]

\section{Introduction}

The $21^{\text {st }}$ century has proposed significant innovations in Latin American regionalism. In the last ten years only, four brand new projects of regional and subregional integration have been launched. In 2004, the Bolivarian Alliance for the Americas (ALBA) was created as an attempt to unite Latin America in the resistance against free markets and the perceived evil side of US-sponsored international capitalism. In 2008, the Union of South American Nations (UNASUR) marked the emergence of Brazilian regional and global status directing regional policy along the lines desired by Brasilia. In 2011, all the 33 Latin American and Caribbean states joined forces to create the Community of Latin American and Caribbean States (CELAC), a platform to allow the continent to speak with one voice in major international venues. Finally, in 2012 the increasing centrality of China and Asia to Latin American economies and development led to the creation of the Pacific Alliance, a bloc uniting those Latin American countries sharing the Pacific shore, good relations with the US and a preference for free markets and liberal economics.

Diversity characterizes these attempts. ALBA, UNASUR and CELAC are essentially political in nature and objectives, while the Pacific Alliance places the economic project at its core. Yet, ALBA also has an economic dimension in the Commercial Treaty of the People (Cusak 2015) and so does UNASUR with the intent to create a common market of South America by 2019 (Resico $2010,358)$. Whether or not these undertakings are successful or consequential is another matter. In their own way the four schemes are an innovation from

* University of Erlangen-Nuremberg, Nuremberg, Germany (gian.luca.gardini@fau.de). 
the past. The fact is that there is not a clear and unique direction in the current wave of Latin American regionalism. On the contrary there are different formulas and underpinning ideologies and objectives, both in the political and economic sphere. This has consequences for the policy management of this complexity too. With such a diverse offer, a first question arises: is it possible to find a coherent and comprehensive explanation for this recent surge of regional projects in Latin America?

The great variety and heterogeneity of integration projects pose an additional challenge in terms of the overall characterization of the current model of regionalism in Latin America. This is problematic too as the most recent initiatives have not replaced but added to the already existing regional organizations and models. In the 1960s, Latin American regionalism was labelled "closed" regionalism in that it attempted to insulate the region from external competition through high trade barriers in order to pursue development by nurturing the local infant industry and by breaking dependence on foreign capital and technology. More or less the entire Latin American continent followed the model. The 1960 Latin American Free Trade Association, the 1961 Central American Common Market, the 1969 Andean Community, and the 1973 Caribbean Community adopted this blueprint. The results were mixed but by the end of the 1970s the model stagnated and was unable to produce social and economic progress.

On the back of the end of the Cold War and of the triumph of the open economy and free trade model, Latin Americans resumed attempts at integration. This time they were inspired by the triumphant economic mantra of liberalization and trade barrier reduction so that Latin American regionalism in the 1990s was labelled "open regionalism." This time too, all Latin American countries, with the exception of Cuba, embraced the model. The 1991 Common Market of the South (Mercosur), the 1994 North American Free Trade Area (NAFTA) and the revitalization and transformation of the Andean Community were the result of this new consensus. Yet, by the end of the decade, this approach had not produced the expected economic and social improvements. Regionalism in Latin America stagnated once again. The model was called into question, generating the wave of new experiments and projects of the last ten years. In the $21^{\text {st }}$ century however, there is not one prevailing model of regionalism and the options available are as varied and creative as they are unable to attract a large and unidirectional flow of followers. So, a second question arises: how to capture and characterize the current multi-faceted situation that encompasses efforts from different historical phases and ideological positions?

This great diversity and sometimes divergence in regional efforts and policies prompts a third crucial question: how to make this complexity work? Or at least tame its contradictions and make it produce public economic and social goods of some sort? This issue links theory-oriented and policy-oriented discussions. Once a theoretical model or a pattern has been identified, this ought to be applied to the 
practice of international affairs not only to explain reality but hopefully to make it work better and produce tangible results.

In search for answers to these three questions, discussion unfolds in two parts. The first part dissects six different approaches to characterize $21^{\text {st }}$ century regionalism in Latin America. It also explores some possible explanations, mainly but not exclusively drawn from the existing literature, for the proliferation of regionalist schemes in Latin America. The second part presents the case for "modular regionalism," the key theoretical argument of this article. It is argued that the concept of modular regionalism provides both for a plausible characterization of the contemporary scenario and for a credible explanation of proliferation of cooperation initiatives. As a major additional asset, it provides a number of policy propositions to attempt to make the overlapping and multifaceted plethora of Latin American integration initiatives work. There has been "enduring frustration on both sides of the theory-policy gap," academia and practitioners (Voeten 2013). In this sense modular regionalism is an attempt to fill in the gap and bridge between the theory and the practice of international affairs. The conclusion wraps up the key arguments and discusses the prevalence of creative cooperation over traditional economic integration in Latin America today.

\section{Latin American regionalism: a puzzle of different narratives}

This section concentrates on the different labels that the literature has coined to capture the multifaceted features of contemporary Latin American regionalism. It will explore where these labels come from; how they characterize the current scenario; how they explain, if at all, the reasons and processes for the coming about of this scenario; and it will discuss some of the limits of each type. It is important to stress from the beginning that the purpose is not to discard or dismiss these approaches but, on the contrary, to try and reconcile them to make sense of a composite picture. Complex phenomena require complex explanations. In other words elements of each approach shed some light on particular aspects of Latin American regionalism. It is not the task of the author, but that of the reader, to select which approaches provide the most convincing elements for analysis.

\section{Post-liberal regionalism}

Post-liberal regionalism was first conceptualized precisely to capture the Latin American regional scenario of the $21^{\text {st }}$ century (Motta Vega and Rios 2007). It is not the result of theories and ideas emanated elsewhere and then more or less successfully transferred and applied to Latin America. This has the great advantage that no methodological adaptation or theoretical stretch is required. The approach finds its intellectual roots in the negative reading of the Latin American experience with neoliberal reforms in the 1990s. From this standpoint, authors 
in this current (Serbin 2012; Motta and Rios 2007; Sanahuja 2012) are set to address the different regional reactions to the failures of the neoliberal project and its corollary of open regionalism. This entails an analysis of how the leaders of emerging regional projects such as ALBA and UNASUR (or its embryonic predecessor the Community of South American Nations) assessed the political, economic and social picture of the early 2000s. Those readings were quite different and as a natural consequences ALBA and UNASUR also proposed quite different solutions as alternatives to (neo)liberalism.

Yet, post-liberal regionalism has some defined features that make it a coherent type. The attempt to go beyond the model of open regionalism and a rejection of the Washington consensus well captures the mood in the first years of the new millennium. In a sought for contrast with the neo-liberal economic mantra and its recipe for regional integration of the 1990s, post-liberal regionalism rejects any desire for or design of supranational integration. It also tries to go beyond traditional economic integration. These principles materialized in a positive agenda that made ALBA and UNASUR significantly different from their predecessors in the previous decade. Both projects focus less on the trade agenda and more on a genuinely political dimension. This means a return to centrality of both the state and development. Both ALBA and UNASUR search for "greater autonomy from the market" and pursue "cooperation in non-trade issues," such as infrastructure, energy, health, education, social inclusion, and security and defense (Sanahuja 2012, 7).

Post-liberal regionalism successfully concentrates on, and explains the cases of ALBA and UNASUR. However, it is less apt to capture phenomena such the Pacific Alliance (which in fact advocates the return of the economy and trade to central stage) or the creation of the Latin American Integrated Market (MILA). This is an initiative to integrate stock exchange operations in Santiago, Bogota and Lima. Interestingly, at the height of anti-neoliberal sentiments, it was civil society and business that pushed for integration of financial services (MILA 2014), a bastion of neoliberal approaches. Also, the insistence on the return of the state and politics is perhaps overemphasized. Latin American regionalism has always been a matter of top down processes governed by states (Gomez-Mera 2013, 223). The unifying principle of the post-liberal approach is the questioning of neoliberalism but not necessarily its outright rejection. Yet it struggles to account for the coexistence of diversity and does not propose any policy solution to make such diversity work.

\section{Post-hegemonic regionalism}

Post-hegemonic regionalism places emphasis on Latin American enfranchisement from the United States and finds its origin in a broader discussion on the declining global power and role of the US. After 2001 in particular, a broad 
discussion on the implications of US retreat for regionalism has taken place, with particular reference to the European Union (Schultz et al. 2001; Telò 2007). The limits and fading of the "unipolar moment" (Krauthammer 1990), the aftermath of 9/11, and the consequences of the new economy of the 1990s left a "turbulent and heterogeneous world system" characterized by "parallel and opposing tendencies towards the decentralization and globalism of world economic and political system" (Telò 2007, 4). This echoes the early observation that globalization prompts both forces of integration and fragmentation (Clark 1997), a remark that perfectly fits Latin America.

The specific emphasis on the decline of the US and the questions it generates about regionalism have been promptly received and applied to Latin America (Riggirozzi and Tussie 2012). Accordingly, the motivations behind and the characterization of the recent proliferation of regional initiatives in Latin America is to be sought in the relative decline of US influence in the continent and the opportunities for autonomous agenda setting that this offers. Latin American regionalism of the $21^{\text {st }}$ century would be an attempt to "move beyond Americanled patterns of integration" and incorporate a strong normative dimension into regional processes (Riggirozzi and Tussie 2012, 1). The recapture of political spaces from Washington and a more autonomous decision-making at the regional level thus constitutes a further step, from post-liberal to post-hegemonic regionalism. This translates into a post-trade model with emphasis on welfare commitments and political integration. This is consistent with the idea that in post-Cold War regionalism, domestic drivers have gradually gained importance over international factors (Van Langenhove and Costea 2005, 4).

It is however acknowledged that the post-hegemonic type in fact coexists with others and probably, in its stricter version, it fully captures a minority of projects (Riggirozzi and Tussie 2012, 12). This type certainly reflects an existing trend in Latin America but may overemphasize its importance for the sake of a normative argument. In fact, the US is still the major economic partner of Latin America overall. While a move away from US models and tutelage is observable in South America this is not necessarily the case in Central America. More to the point, integration models largely based on free trade are still alive (CARICOM, Mercosur, CAN, NAFTA) and kicking (Pacific Alliance, CAFTA-DR). The emphasis on the social and the political is now common to institutions of all political signs in Latin America, conservative and progressive, both at the national level as well as at the regional (as Mercosur and also the Pacific Alliance demonstrate). With the exception of ALBA, capitalism, open economy and free trade are still underpinning most integration projects in Latin America. The rupture between Washington's ideological and policy preferences and $21^{\text {st }}$ century Latin America may have been significantly overestimated (Petras 2006). And the post-hegemonic regionalism approach does not shed any light on how it coexists in practice with previous initiatives. 


\section{Third-generation regionalism}

This approach stresses the external projection, with global aspirations and presence, which partly characterizes Latin American regionalism in the $21^{\text {st }}$ century. Same as post-hegemonic regionalism, also the third generation regionalism has its roots in the implications of the relative decline of the US for regionalism and the reconfiguration of international spaces for manoeuver for the European Union. The point of departure is the acknowledgement of a developing multi-polar system at the beginning of the new millennium, the increasing interdependence among nations and regions, and the fears that the multilateral trading system may not perform effectively (Schultz et al. 2001). Analysis concentrates on the European Union and how it presents such peculiar differences from any other initiative that it constitutes a unique case hardly transferable to other parts of the world (Soderbaum, Stalgren and Van Langenhove 2005, 372). This is particularly evident in the external dimension of the EU, which gave rise to the literature on "the EU as a global actor" (Soderbaum, Stalgren and Van Langenhove 2005; Soderbaum and Van Langenhove 2006).

Third generation regionalism in its original formulation rested on three principles and one note of caution. Firstly, regional organizations (but basically the EU) are increasingly engaged with out-of-area policies and concerns. Secondly, they are more and more active in inter-regional dealings and global agreements. Thirdly, regions become more actively involved in the United Nations. The accompanying warning was that, half-way through the first decade of the 2000s, third generation regionalism was still a largely normative concept, and that the EU could be considered as a "prototype presenting some of the characteristics of a future 'third generation' regionalism" (Van Langenhove and Costea 2005, 12). Yet, the idea has been applied to Latin American regionalism to mark the normative content and the extra-regional scope of some of the initiatives being carried out in the new millennium (Muhr 2011).

The idea of the emergence of a third generation of regionalism in Latin America too is linked to some of the key tenets of CELAC, UNASUR and ALBA. The underpinning assumption is that these three organizations exercise some sorts of extra-regional actorness by virtue of their commitment to shaping global governance (Muhr 2011,7). While it is correct that all aspire to change somehow regional and global dynamics and that all engage with some sort of out of area activity, the weight of these undertakings should not be overestimated. To begin with, actorness presupposes something more than aspiration in terms of capacity to negotiate autonomously and commit on behalf of member states. However, this is not the case in any of these three organizations. The evidence provided about ALBA's engagement with the UN regarding the UN Framework Convention on Climate Change (Muhr 2011, 15) is quite thin. Also, if the proposition is that "third generation regionalisms in LAC [Latin American countries] are political 
projects within post-neoliberal and counter-imperialist rationales" (Muhr 2011, 16), it has to be noted that non-counter hegemonic organizations such as Mercosur and the Pacific Alliance also have beyond the area aspirations and initiatives. One may in fact wonder if Mercosur and the Pacific Alliance already represent a fourth wave of regionalism in Latin America combining neoliberal pillars with a desire to introduce more equitable and development-oriented rules in the international system.

The third wave regionalism type has the merit to shed light on the international/global dimension of the aspirations of some regionalist projects in Latin America. In its basic formulation, "the essence of third generation regionalism is thus that a region sees itself as a fully-fledged actor in the theatre of international relations. [...] It also implies that a region engages in bilateral relations with other regions or states" (Van Langenhove and Costea 2005, 15). In terms of selfperception it may be the case that a number of Latin American regional projects like to see themselves as relevant international actors. Whether or not the rest of the international community does it is a different matter altogether. Regarding bilateral relations with other regions or states, paradoxically it is the non-counter-hegemonic projects that perform best, as the institutionalized dialogue between the EU and Mercosur, CAN and SICA demonstrates. The EU-CELAC summit so far is just a new label for an old and well-established mechanism, the EU-Latin American and the Caribbean summitry. No discussion of how third wave regionalisms and projects from previous waves coexist in diplomatic, political and economic practice has been conducted, thus neglecting a crucial policy-relevant point.

\section{Spaghetti-bowl regionalism}

The metaphor of the spaghetti bowl renders the intricacy and juxtaposition of many regionalist projects. As a consequence, the identification and application of rules are extremely complex and overlapping regionalisms end up producing less than optimal effects. It is difficult to disentangle the mass of spaghetti in a bowl. So is to disentangle overlapping and intertwining regional integration agreements and regulations. If one thinks that the spaghetti bowl metaphor is quite daring, its original formulation was in fact even stronger. In the mid-1990s the proliferation of preferential trade agreements was in fact also defined as an "orgy, with bodies intertwined and reaching out in different directions" (Bhagwati $1995,4)$. Although both comparisons appeared in the same article, academia has subsequently privileged the gastronomic over the anatomic approach.

The application of the spaghetti-bowl regionalism type to Latin America emphasizes the negative effects of proliferation. Countries subscribe to many different agreements, some even contradictory, thus making the hierarchy of applicable rules quite complex. The compatibility of ALBA and CAFTA-DR rules (Nicaragua) or ALBA and Mercosur principles (Venezuela) or ALBA, UNASUR, 
CAN and soon Mercosur commitments (Bolivia) is at least questionable. In particular, it is difficult to understand how a country, Bolivia, can be part of two different customs unions, CAN and Mercosur. This casts some doubts about the viability and meaning of such an abundant juxtaposition of membership and allegiances. But it also questions issues of representation and effectiveness. Who truly/best represents South American countries as a group in political and non-trade affairs: Mercosur, UNASUR or CELAC? What is the credibility of the statements and commitments of each organization? Is there a duplication of functions and possibly room for divergent positions on the same topic in organizations representing at least some of the same members?

The spaghetti bowl type has the merit to offer a compelling, although pretty grim, understanding of the situation as well as a credible explanation for it. The multiple and simultaneous participation of Latin American countries in different ventures was singled out as problematic even before the recent proliferation, with Bolivia as a paradigmatic case in point (Abugattas Majluf 2004, 9). The explanation of both regional diversity and proliferation would reside in the diversity of domestic political and economic interests. When these are displayed to shape foreign and trade policy, they tend to reach out "for prizes in a variety of unrelated political arenas" and to give rise in turn to different behaviors depending on the counterparts, the issues at stake, and the forum (Bhagwati 1995, 8). And if prizes, it doesn't matter how limited, are up for grabs, then the "fear of exclusion" also becomes a key driver for Latin American countries to join new regionalist ventures (Abugattas Majluf 2004, 5).

This approach accounts for a good number of things and only has minor limitations. It has even a predictive dimension in that a relentless proliferation would dilute commitments, reduce expectations, and likely enlarge membership leading to "multilateralizing regionalism" (Baldwin 2006). This may be the case for instance with UNASUR that some commentators understand as a sort of merge of CAN and Mercosur (Schelhase 2011). Yet, the spaghetti bowl type tends to underestimate the achievements and vitality of Latin American regionalism. Progress in democracy, peace, physical integration, and to an extent the advance of trade and a normative regional agenda have been accomplished. Regarding policy, incompatibility may well describe the current situation, but it does not say much about possible solutions to manage this complexity more efficiently.

\section{Rhetorical regionalism}

Emphasis on normative and rhetorical commitments that produce actual effects underpins the concept and type of rhetorical regionalism. In essence the current picture of Latin American regionalism would be the result and reflection of a rhetoric and narrative exercise. Repeated through time and widely accepted, this shapes political interests, values and legitimacy and therefore it determines policy 
choices too. The case for rhetoric determining regional dynamics and policies was first constructed with reference to the EU and NATO enlargement to Central and Eastern European countries (Schimmelfennig 2003). Theoretically, the idea of a rhetorical action is linked to "the strategic use and exchange of arguments based on ideas shared in the environment of the proponents and intended to persuade the audience and the opponents to accept the proponents' claims and act accordingly" (Schimmelfennig 2003, 199).

The rhetorical action process finds a perfect fit in Latin America. Not only there is a gap between Latin American regional discourse and achievements on the ground (Malamud 2005; Vaillant 2010). Most of all rhetoric produces effects. Latin America's "rhetorical, almost theatrical, support for continental solidarity and integration" has a long and well established tradition dating back to the founding fathers of independence (Gardini 2011, 250). This narrative is accepted both at the elite and the popular level. It thus constitutes a key element of Latin American political culture and logic of appropriateness. Commitment to integration and regionalism is a canon of legitimacy for politicians thus framing political discourse and, to an extent, policy choices too. The rhetoric of support for integration contribute to the fact that once a new integrationist initiative is launched, it is very difficult for political leaders not to support it, lest pay the political cost in terms of credibility, votes and neighbors criticism. Even if the use of rhetoric is sometimes merely opportunistic, it ends up producing constraints. Once a country joins a group it becomes bound by the rules of that forum. Rhetoric thus produces two types of incentives to regional cooperation. On the one hand it makes it difficult to defect from new initiatives. On the other, it bounds countries to the norms of the organizations they join.

The rhetorical regionalism type has strong theoretical foundations. Also it is well grounded in Latin American traditions and acknowledges its own limitations. The concepts of rhetorical action and rhetorical entrapment have a coherent philosophical construction and find empirical confirmation in both Europe and Latin America. Additionally, rhetorical regionalism relies on the weak mechanism of compliance at the international level (Schimmelfennig 2003, 215), which is a factor that well explains the coexistence of very diverse forms and instruments of regional cooperation and integration in Latin America. Interestingly, rhetorical regionalism also acknowledges that "actors use as many mechanisms as possible simultaneously $[\ldots]$ to induce their opponents to cooperate" (Schimmelfennig $2003,215)$. This shows how rhetorical regionalism and action are one possible approach to understand ad explain regionalism in Latin America, but other accounts are equally possible. This is a healthy and welcome example of theoretical pluralism and tolerance. Still, the weight of given and vested interests and structural situations appear to be downplayed or even neglected in this type. Not to mention the absence of any policy indication. 


\section{The peak of regionalism}

Also specifically conceived to capture the conundrum of Latin American integration is the suggestion of a peak of regionalism (Malamud and Gardini 2012). Here regionalism is essentially understood as traditional economic integration and the argument points to the emergence of, or return to, creative forms of cooperation. Empirical observation shows a proliferation, fragmentation and divergence between integrationist initiatives. These result in multiple allegiances and memberships that, de facto, multiply loose commitments without deepening significantly any aspect of regionalism or collective decision-making. Structural limitations due to geography as much as to economic production and trade flows regionally and globally, make further economic integration or shared sovereignty very unlikely. The product would be a flat curve where Latin American regionalism, after decades of growth has reached a peak and now continues flat at the same level of commitment and intensity but without much hope of significant advancement or deepening. The peak of regionalism as economic integration does not exclude but on the contrary envisages other forms of cooperation. These have materialized in the recent wave of regionalist proliferation and diversity.

In this context, the contours of regionalism have changed significantly. Economic integration has become a bilateral or geographically diffused multilateral phenomenon rather than regional. The dynamics of a global economy favor factors of cooperation such as supply-demand links and added value chains rather than geographic proximity per se. Yet regionalism is still a compelling foreign policy in Latin America. However, its causes, goals and outcomes are no longer what they used to be. Politics tends to prevail over economics, and ideological and normative agendas may blur economic considerations. In any case, aspiration to holistic regionalism and integration is no longer on the agenda. More issue by issue discussions take place. A country's interests do not necessarily coincide with its immediate economic advantage. Diversity of national interests, and as a consequence of drivers to integration, is acknowledged (Tussie 2009). So the Pacific Alliance, ALBA, CELAC and UNASUR reflect fast changes in the national, regional and international scenarios ranging from new geostrategic concerns (Asia-Pacific) and leadership aspirations (Venezuela and Brazil) to ideological differences (counter-hegemonic and join the club approaches) and competing priorities (solidarity, growth, physical integration, social agenda).

The merit of this approach is twofold. On the one hand, it coins an eye-catching label that well captures the difficulties in defining progress in Latin American regionalism. On the other, it points to the exhaustion of traditional integration instruments and the vitality of new experiments that together signal the prevalence of loose, ad hoc and functional cooperation over more rigid, institutionalized integration. Yet, the peak of regionalism approach leaves room to define further this new wave of cooperation. What does this look like? Does 
it have a coherent underpinning design? How may it evolve? Why and how is such diversity compatible? The next section proposes a typology that builds on the strengths of the six already discussed and attempts to address their shortcomings.

\section{Towards modular regionalism in Latin America}

The previous section has dissected how the current wave and variety of Latin American regionalisms can be characterized and explained. The key features of the contemporary picture, and the associated explanations for its emergence, can be summarized in six arguments and types: the overcome of open regionalism (post-neoliberal), enfranchisement from the US (post-hegemonic), increased international presence and networks (third generation), growing intricacy and juxtaposition (spaghetti bowl), gap between political narrative and reality (rhetorical regionalism), and preference for cooperation over traditional economic integration (peak of regionalism). All these approaches provide for credible, although not necessarily acceptable or exhaustive, explanations of the current situation or some aspects of it. However, they all fall short of a characterization that fully captures and accurately comprehend the overall direction and historical moment of regionalism in Latin America. Also, their prescriptive and policy-oriented dimension is at best loose.

This section makes a case for modular regionalism as a framework that builds on and encompasses the previous approaches and, at the same time, accounts for the whole picture of contemporary regionalism in Latin America. The idea of modular regionalism comes from the concept of "modular multilateralism" developed in the early 1990s with reference to North-South cooperation (Feinberg and Boylan 1991). The similarities between the empirical contexts of multilateralism in the 1990s and Latin American regionalisms in the 2000s are striking and make a good case to borrow the idea of modular multilateralism and turn it into modular regionalism. Also, solid theoretical reasons make the original concept transferable to a compatible and comparable environment.

The key features of the multilateral context of the early 1990s offer significant commonalities with the Latin American regional background of the 2000s. In 1990s, the major tenets underpinning modular multilateralism were: strong economic, commercial and cultural ties among the countries concerned; the declining position of the United States; an increasingly varied set of issues of common concern and interest such as trade, finance, development strategies, ecology and human rights; the surge of non-state actors, including NGOs and business corporations, that made the international milieu an ideal terrain for a varied range of players; and the disparity in power and level of developments (Feinberg and Boylan 1991, 6). These characteristics perfectly describe the current situation in Latin America, as also highlighted by the set of six types. 
Besides similarities in empirical backgrounds, there are good theoretical foundations to support a comparison, and assimilation, between multilateralism and regionalism. In the first place regionalism is a form of multilateralism, and this is particularly evident in the Latin American case (Legler and Santa-Cruz 2011). Secondly, the Latin American regional order is based as much on relations between states as it is on relations between sub-regional blocs. This would meet the definition of "regional multilateralism" that implies "relations between all regional organizations, resulting in a distinct mode of global governance built on regions" (Soderbaum, Stalgren and Van Langenhove 2005, 379). Replacing the expression global governance with regional governance, one obtains a perfect picture of the current Latin American scenario. Echoing Hettne's discussion of a "European world order" based on relations between regions (Hettne 2005), a Latin American order may be based on relations between sub-regions and sub-regional projects, precisely the point about the coexistence and variety under scrutiny here.

Once established that modular regionalism has sound foundations and that its applicability to Latin America is a credible exercise, it is now time to define modular regionalism, what advantages it brings and what offers that other approaches missed. Following the matrix of the original formulation of modular multilateralism (Feinberg and Boylan 1991), modular regionalism distinguishes itself for three key characteristics. Firstly, modular regionalism is both a theoretical and applied framework for cooperation. Secondly, it emphasizes where/when common ground can be achieved but does not ignore complexity. In these two senses the practical and policy-oriented element is a great asset that other types do not offer. Thirdly, modular regionalism, like its prototype modular multilateralism, is multilateral in that many players come to the table at the same time, and it is modular in that actors at the table at any one time will shift according to the issue at hand (Feinberg and Boylan 1991, 7). This helps conceptualize and systematize the great variety and proliferation observable in Latin America.

Overall, the major asset of the modular regionalism typology is that it convincingly displays a number of theoretical functions and focuses on policy relevance. It is quite strong in the descriptive, predictive and prescriptive dimensions although less so in the explanatory one. This means that it has the potential to fully describe and capture this overall moment of Latin American regionalism as a whole movement. In other words, modular regionalism is not limited to the explanation of one or more schemes but defines a comprehensive trajectory, a mood, by the same token as open or closed regionalism defined their respective epochs. The prescriptive and predictive dimensions add a policy-relevant contribution that is more evident than in any other type.

The weaker aspect is in a way its explanatory dimension. The same applies though to the concepts of open and closed regionalism. These did not account for the creation of one or more specific projects but captured the underpinning 
spirit and principle of a phase. Modular regionalism does this for our time. The explanatory dimension remains implicit in the acknowledgement of the context of and premises to the modular form of regionalism. By largely accepting those context and premises (one compares the key tenets of each of the six types with the major tenets underpinning modular multilateralism) modular regionalism borrows from those types and builds on their plurality of explanations, leaving the selection of and preference for one or a combination of these to the reader. The theoretical soundness and the policy relevance of modular regionalism are displayed in the following four dimensions.

\section{Descriptive}

In its descriptive dimension, modular regionalism is a device to capture the interplay of multiple actors, issues and tables (or projects). By its own nature, modular regionalism is based on modules, then presupposing a plurality of them. That is to say that the architecture of Latin American regionalism is structured in different projects (modules) competing for members; the latter can choose which module(s) to join depending on the issue, time and opportunity. The decision depends on both national and international factors and allows for multiple memberships and non-exclusiveness of alliances and interests. Once again this depends on the issue, timing and circumstances. As an example, Venezuela, Bolivia and Nicaragua, can embrace the Bolivarian principles of ALBA to mark their ideological stance and preference. But they can also join DR-CAFTA or Mercosur if that suits their economic or political interests. By the same token UNASUR can accommodate members with different ideological signs but united in the search for genuinely regional political and defense solutions. This flexibility may well signal pragmatism rather than ideological incoherence. Overall, following the 1991 formulation, diversity among participants is assumed as is variety among issues (Feinberg and Boylan 1991, 7).

Instead of struggling with the diversity characterizing Latin American regionalism today, modular regionalism fully accepts it and makes it one of its foundational elements. This accounts for example also for the plurality of actors involved in regional dynamics, from government and their agencies (top down approaches), to private sector and social movements (bottom-up approach) to extra-continental players that define Latin American regional strategies such as the US and increasingly Asia (external drivers). The private sector and in particular the stock exchange operators, were at the roots of the MILA project, now under the umbrella of the Pacific Alliance, while ALBA includes a Council of Social Movements in its organizational architecture and Mercosur has a social dimension. The actual decisional weight of these actors is a different matter though. 
Analytical

In its analytical dimension, modular regionalism provides a framework to account for the structure of regional relations. Its strength lies with its ability to encompass and draw from the six types presented. A modular structure of regional projects allows to accommodate the desire to overcome liberal approaches, the enfranchisement from the US, the inclination towards international and global issues and forums, the intricacy and juxtaposition of efforts, the gap between rhetoric and reality on the ground, and the abandonment of traditional economic integration in favor of more flexible forms of cooperation. Admittedly, this view is half-way between the descriptive and the analytical. Yet its purpose is not to explain the creation or development of one or more specific integration initiatives but to make sense of the whole picture of contemporary Latin American regionalism. In this sense, modular regionalism not only best captures the situation but provides tools to explain the compatibility and coexistence of such diverse initiatives through its modular architecture. More in depth, modular regionalism makes space for more detailed explanations of this coexistence, such as low levels of commitment, compliance and enforcement; the serving of national interests; and the power of rhetorical attraction without real public debate on the consequences and deep implications of regional commitments.

\section{Predictive}

The predictive dimension of modular regionalism provides a tool to project interactions among Latin American actors. Drawing on the original formulation of the 1990s, three defining features of those relations are envisaged in the shortterm: focus on issue-based negotiations, formation of coalitions of like-minded states and win-win issues to be tackled first (Feinberg and Boylan 1991, 9-10). This prediction is absolutely correct when applied to the four Latin American projects created between 2004 and 2012. ALBA and the Pacific Alliance provide examples of coalitions of like-minded states; UNASUR in turn embodies the win-win issue approach where controversial topics are left on the side, while CELAC deals with issue- or partner-based negotiations.

In the longer term, the original model predicts a surge in cooperation to avoid interdependence costs, a convergence of development strategies, and the development of institutions to cope with complexity. The surge in cooperation in a way materializes in the proliferation of initiatives and the peak of regionalism argument. The convergence of development strategies, although more problematic and arguably far from being achieved, is detectable in the Venezuelan and Bolivian rapprochement and accession to Mercosur and in the several efforts at coordination within UNASUR and CELAC. The point here is a trend, not necessarily its success. Admittedly, the institutionalization of integration and the creation of 
common structures is partly losing ground. While institutionalization efforts are being made for instance within UNASUR, these have been relatively absent so far within CELAC. But this is perhaps where the predictive dimension blurs with the more prescriptive one, where policy propositions are designed to make modular regionalism work.

\section{Prescriptive}

The prescriptive dimension of modular regionalism offers a number of policy recommendations to make complexity work. In other words, modular regionalism is also a model for collective decision-making (Feinberg \& Boylan 1991, 8). A word of caution is necessary at this stage. Given the great diversity of existing projects, the prescriptive dimension here only pretends to provide policy indications to manage complexity; it does not pretend to propose specific reforms and it does not belittle the labyrinth of Latin American politics and vested interests. Among the most significant propositions are:

- Highly specific modules with regard to substance, scope and time horizon. This means that in order to make the plethora of Latin American regional organizations work, each should ideally pursue a specific and well-defined role; specialization is the key word.

- Ad hoc secretariat and coordination mechanisms. This seems to be almost trivial if understood as the creation of a further body to coordinate the existing ones. But this need has been acknowledged by Latin American countries and both CELAC and UNASUR, in different contexts, aspire to a coordinating role. Coordination between highly specialized institutions has the potential to reduce duplications and overlapping.

- Creative approach to problem-solving. This seems indeed to be the direction taken by Latin American regionalisms. For example, the proliferation of organizations and summits entails an increase in costs and pressure on leaders' agendas. The Pacific Alliance has had recourse to a virtual summit conducted in video-conference. This is an example of creative problemsolving that could be applied to other regional summits with a significant save of resources.

- Need for leadership. This is a well-established argument to manage complexity in both Management (Kotter 1990) and Political Science studies (Nye 2013). The problem with Latin America is the overabundance of half-hearted would-be leaders, the ambiguity of the Brazilian status, swinging between a consensual leader (Burges 2008) and a leader without followers (Malamud 2011), and the resistance of other countries to accept someone else's lead. The EU resorted to a consensus on shared leadership in the absence of one state or one coalition leadership but the European 
case is so unique that it is not clear how this can be applicable to Latin America. Perhaps the proposal of a "collective bargainer, wherein clusters of nations unite behind a single position, voiced by one spokesperson for a given issue" (Feinberg \& Boylan 1991, 12) is a more practicable_-although not easy-solution for Latin America.

- Special differential treatment. This is the path followed by ALBA but the principle has recently been accepted by Mercosur too. For regionalism to work there shall be an acknowledgement of the different conditions and needs of members. But also an acceptance and a will to take tangible measures to address these disparities, which takes to the final point.

- Transfer of concessional development assistance. For modular or any regionalism to work, it is important to develop regional cohesion and solidarity. The experience of the EU DG Region and structural funds is enlightening in this respect. The Mercosur Fund for Structural Convergence (FOCEM) is a step in this direction. But regional consensus on and commitment to this are indispensable to make a modular architecture of regionalism work in practice.

\section{Conclusion}

The current proliferation of "Latin American regionalisms" reflects the diversity of interests and visions in the continent. In the absence of a minimum common denominator for convergence, modular regionalism is the best one can hope for. It offers compelling answers to the three questions informing this article, namely how to explain the current proliferation of regionalisms in Latin America, how to characterize overall this historical phase, and how to make regional complexity in Latin America work. As compared to other theoretical types designed to capture Latin American regionalism in the $21^{\text {st }}$ century, modular regionalism combines a strong descriptive dimension with a plausible and pluralist explanatory dimension. It also formulates predictions for the future. Most of all, modular regionalism offers a prescriptive dimension, a set of policy propositions aimed to make regional complexity and overlapping work. These propositions rest on the assumption that there is the political will to do so and does not ignore the difficulties of such undertaking.

Modular regionalism, with its "pick and choose" approach, also signals the prevalence of cooperation over integration. Regionalism is a multi-dimensional and multi-faceted phenomenon (Hurrell 1995). Cooperation, integration, as well as identity are all elements of regionalism. But when it comes to the involvement of states, as is mainly the case in Latin America, cooperation and integration are the key concepts. They are different phenomena. To use them interchangeably is inappropriate both conceptually and practically. Cooperation comprises 
intergovernmental agreements or regimes that may entail the creation of formal institutions or may be based on much looser structures, involving pattern of regular meetings with some rules attached. Integration is a sub-category of cooperation that involves specific policy decisions designed to reduce or remove barriers to mutual exchange of goods, services, capital, and people (Hurrell 1995, 42-43). The acceptance of this definition helps clarify the Latin American conundrum and to bridge the gap between rhetoric and practice. In spite of some attempts at integration, especially in the 1990s (Mercosur, CAN), Latin America is now pursuing cooperation. This means a move towards a varied set of agreements in a number of issue-areas beyond the economy and with loser mechanisms of commitment and compliance.

The new wave of Latin American regionalism in the $21^{\text {st }}$ century is a wave of cooperation, not integration. This is why so many diverse projects can coexist. This is also why political discourse and the media talk integration while diplomacy and agreements on the ground concern in fact cooperation. In practical terms, with cooperation the economic side can be neglected or stretched to almost barter arrangements, such as in ALBA. This is not possible with integration. Post-neoliberal approaches are perfectly possible with cooperation but they would struggle within a political and legal framework of integration. This is why it is important to understand what exactly we are talking about. No normative position or preference is suggested, but cooperation is certainly more malleable than integration. The idea of modular regionalism explains the coexistence and proliferation of cooperation initiatives. Overlapping or multi-layered regionalism are present in other regions of the world too. To what extent the concept of modular regionalism, very suitable for Latin America, is applicable to other regions is an avenue for further research.

\section{Bibliographic references}

Abugattas Majluf, L. (2004), Swimming in the Spaghetti Bowl: Challenges for Developing Countries under the new Regionalism, UNCTAD Policy Issues in International Trade and Commodities Study Series No. 27, New York and Geneva.

Baldwin, R. (2006), Multilateralising Regionalism: Spaghetti Bowls as building Blocs on the Path to Global Free Trade, National Bureau of Economic Research Working Paper Series No. 12545, Cambridge MA.

Bhagwati, J. (1995), US Trade Policy: The Infatuation with FTAs, Columbia University Discussion Paper Series No. 726.

Burges, S. W. (2008), Consensual Hegemony: Theorizing Brazilian Foreign Policy after the Cold War, International Relations, 22: 1, pp. 65-84.

Clark, I. (1997), Globalization and Fragmentation: International Relations in the Twentieth Century, Oxford: Oxford University Press. 
Cusak, A. (2015 forthcoming), The Bolivarian Alliance for the Peoples of Our America (ALBA) and the Dilemmas of Postneoliberalism in Latin America and the Caribbean, Basingstoke: Palgrave MacMillan.

Feinberg, R. and D. Boylan (1991), Modular Multilateralism. North-South Economic Relations in the 1990s, Washington DC: Overseas Development Council.

Gardini, G. L. (2011), Unity and diversity in Latin American Visions of Regional Integration, in G.L. Gardini and P. W. Lambert (Eds), Latin American Foreign Policies. Between Ideology and Pragmatism, Palgrave MacMillan, New York, pp. 235-254.

Gomez Mera, L. (2013), Power and Regionalism in Latin America, Notre Dame Indiana: University of Notre Dame Press.

Hettne, B. (2005), Reconstructing World Order, in Farrell, M., B. Hettne \& L. van Langenhove (eds) Global Politics of Regionalism, London: Pluto Press.

Kotter, J. (1990), A Force for Change: How Leadership Differs from Management, New York: The Free Press.

Krauthammer, C. (1990), “The Unipolar Moment”, Foreign Affairs, 70: 1, pp. 23-33.

Legler, T. and A. Santa-Cruz (2011), El patrón contemporáneo del multilateralismo latinoamericano, in Legler, T. and A. Santa-Cruz (Eds), Pensamiento Propio, special issue, No. 33, January-June, pp. 11-34.

Malamud, A. (2005), Mercosur Turns 15: Between Rising Rhetoric and Declining Achievement, 18: 3, Cambridge Review of International Affairs, pp. 421-436.

Malamud, A. (2011), A Leader Without Followers? The Growing Divergence between the Regional and Global Performance of Brazilian Foreign Policy, Latin American Politics and Society, 53: 3, pp. 1-24.

Malamud, A. and G. L. Gardini (2012), Has Regionalism Peaked? The Latin American Quagmire and its Lessons, International Spectator, 47: 1, March, pp. 116-133.

MILA (2014), Historia, online: http://www.mercadomila.com/QuienesSomos (last accessed 10/09/2014).

Motta Vega, P. and S. Rios (2007), O Regionalismo pós-liberal na América do Sul: origens, iniciativas e dilemas, Santiago de Chile: CEPAL Serie Comercio Internacional, $\mathrm{Nr} 62$.

Muhr, T. (2011), Conceptualisng the ALBA-TCP: Third Generation Regionalism and Political Economy, International Journal of Cuban Studies, 3:2/3:3, pp. 98-115.

Nye, J. (2013), Presidential Leadership and the Creation of the American Era, Princeton: Princeton University Press.

Petras, J. (2006), US-Latin American Relations: Ruptures, Reaction and the Illusion of Time Past, Dissent Voice, November 2 ${ }^{\text {nd }}$, Online: http://www.dissidentvoice.org/Nov06/Petras02. htm (last accessed 10/09/2014).

Resico, M. (2010), Introduccion a la Economia Social de Mercado, Buenos Aires: Konrad Adenauer Stiftung. 
Riggirozzi, P. and D. Tussie (2012), The Rise of Post-hegemonic Regionalism, London, New York, Dodrecht and Heidelberg: Springer.

Sanahuja, J. A. (2012), Post-liberal regionalism in South America: the case of UNASUR, EUI Working Papers 05/2012, Florence.

Schelhase, M. (2011), The Changing Context of Regionalism and Regionalisation in the Americas: Mercosur and beyond, in Shaw, T. M., J. A. Grant and S. Cornelissen, The Ashgate Research Companion to Regionalisms, Farnham and Burlington: Ashgate, pp. 175-191.

Schimmelfennig, F. (2003), The EU, NATO and the Integration of Europe. Rules and Rhetoric, Cambridge: Cambridge University Press.

Schultz, M., F. Söderbaum, and J. Öjendal (2001), Introduction. A framework for understanding regionalization, in Schultz, M., F. Söderbaum, and J. Öjenda (Eds), Regionalization in a Globalizing World, London: Zed Books, pp. 1-17.

Serbin A. (2012), Déficit democrático y participación ciudadana en el marco del regionalismo post-liberal, in Serbin A., L. Martinez and H. Ramanzini Junior (Eds), El regionalismo "post-liberal" en América Latina y el Caribe: Nuevos actores, nuevos temas, nuevos desafíos, Buenos Aires: CRIES.

Soderbaum F., P. Stalgren and L. Van Langenhove (2005), The EU as a Global Actor and the Dynamics of Interregionalism: a Comparative Analysis, European Integration, 27: 3, pp. 365-380.

Soderbaum F. and L. Van Langenhove (Eds) (2006), The EU as a Global Player: The Politics of Interregionalism, London: Routledge.

Telò, M. (2007), Introduction: Globalization, New Regionalism and the Role of the European Union, in Telò, M. (Ed.) European Union and New Regionalism. Regional Actors and Global Governance in a Post-hegemonic Era, Aldeshot: Ashgate, pp 1-18.

Tussie, D. (2009), Latin America: Costrasting Motivations for Regional Projects, Review of International Studies, 35: 1, pp. 169-188.

Vaillant, M. (2010), Interview with the author, Montevideo, 9 July 2010. M. Vailant is Professor of International Trade at the Universidad de la Republica, Montevideo, and a former member of the MERCOSUR Technical Assistance Sector.

Van Langenhove, L. and A. Costea (2005), The EU as a Global Actor and the Emergence of 'Third Generation' Regionalism, UNU-CRIS Occasional Papers 0-2005-14.

Erik Voeten, What do policymakers want from academics?, The Washington Post, 25 September 2013, Online: http://www.washingtonpost.com/blogs/monkey-cage/wp/2013/09/25/what-dopolicymakers-want-from-academics/ (last accessed 6 Nov. 2014). 


\begin{abstract}
This article addresses three questions: why there was a surge in regional cooperation projects in Latin America in the last decade; how to characterize the current multi-faceted scenario; and how to make this complexity work. After a review of six theoretical perspectives, an original conceptual approach is proposed: "modular regionalism." This credibly answers the three questions and offers policy recommendations.
\end{abstract}

Keywords: cooperation; integration; Latin America; regionalism.

\title{
Resumo
}

Este artigo analisa três questões: por que houve um aumento de projetos de cooperação regional na América Latina na última década; como caracterizar o cenário atual multifacetado; e como fazer essa complexidade funcionar. Após uma revisão de seis perspectivas teóricas, propõe-se uma abordagem conceitual original: "regionalismo modular". Este trabalho responde de forma crível as três questões e oferece recomendações nas políticas.

Palavras-chave: cooperação; integração; América Latina; regionalismo. 